\title{
From growth to decline? Demand-absorbing private higher education when demand is over
}

\author{
M. Kwiek
}

University of Poznan, Poland

\subsection{Introduction: European and global growth patterns in private higher education}

The growth of the private sector in higher education in Europe, in terms of the number of institutions and the share of enrollments in national systems, has been an educational phenomenon of postcommunist transition countries. ${ }^{1}$ As Daniel C. Levy (2010, p. 10) points out, though, "one of the key trends in international higher education, the rapid expansion of the private sector now holds one-third of all global enrollments. However, the growth is not unbroken or inexorable and sometimes stalls and even reverses." Poland is an example of the reversal in question. While the expansion era (1990-2005) was characterized by external privatization (that is, private sector growth), combined with internal privatization (or the increasing role of fees in the operating budgets of public universities), the current contraction era (2005-25, and possibly beyond) is characterized by what we term "de-privatization." De-privatization also has external and internal dimensions; the gradual decline in private sector enrollments is combined with a decreasing role of fees in funding for public universities (see Kwiek, 2015).

Private higher education in postwar Europe, before its phenomenal growth in postcommunist countries after 1989, emerged first in Spain (1973), Portugal (1979), and Turkey (1981). Following Levy (2002), the distinction between elite provision and access provision can be used in exploring this sector: in Western Europe (Austria, Germany, Italy, Portugal, France, Spain, and Russia), private higher education sectors correlate with elite-providing roles; in contrast, in most postcommunist transition countries, these sectors correlate with access-providing roles (Albania, Bulgaria, Estonia, Poland, Romania, Russia, Ukraine, and Portugal; with Russia and Portugal being included in both categories, Fried, Glass, \& Baumgartl, 2007, pp. 645-646). In Poland, the number of semi-elite private providers is marginal: in all probability, in the range of 10-20 out of 283 in 2015. In some countries (such as, for example, Sweden, Belgium, or the Netherlands), nominally private institutions are funded in practice from the public purse in various forms and under different umbrellas. In this paper, we

\footnotetext{
${ }^{1}$ Exceptions include especially Portugal, as well as, to a smaller extent, France, Italy, and Spain; see in particular Portugal as discussed in the last decade in Neave and Amaral (2012), Teixeira (2012), Teixeira and Amaral (2007), and Teixeira and Amaral (2001).
} 
consider private as only those institutions which meet the definition of independent private institutions formulated by the OECD in its Handbook for Internationally Comparative Education Statistics: Concepts, Standards, Definitions and Classifications; these are the institutions that receive less than $50 \%$ of their core funding from government agencies and whose staff is not paid by such agencies (OECD, 2004). ${ }^{2}$

The global demographics of private higher education is such that the major center of the sector is East Asia, with about $80 \%$ of all students enrolled in private universities in Japan, South Korea, Taiwan, and the Philippines; in the USA (somehow surprisingly) only 20\%; in Western Europe, on average 10\% or less; in Latin America, over 50\% in Brazil, Colombia, Peru, and Venezuela and finally, in European postcommunist transition countries, and in some post-Soviet republics, where the most rapid growth took place after 1989, up to 30\% (see the most recent data on the PROPHE: Program for Research on Higher Education website). As Levy, PROPHE's director, puts it, "where public budgets do not meet the still rapidly growing demand for higher education, students pay for alternatives" (Levy, 2002, p. 4), and this is what happened in Poland following 1989. While Western Europe has not in general witnessed the emergence (or substantial strengthening, depending on the country) of the private sector in higher education, in several postcommunist transition countries in Europe, for a variety of reasons, the private sector emerged as a demand-absorbing competitor to the traditional, elitist, faculty-centered and often inaccessible public sector. The differences among the transition countries are significant, though, and in this chapter our focus is Poland.

\subsection{The changing public-private dynamics}

The private sector in Poland cannot be explored outside of the context of the public sector: its future is closely linked to the changing public-private dynamics in the whole system. It is useful to explore its future in the context of two major ongoing processes:

- large-scale reforms of public higher education (see Kwiek, 2014) and

- broad, long-term demographic changes.

The question of its future is much larger, though; as Peter Scott asks in his study on Central Europe, are higher education systems in the region trendsetters for Europe (providing models for other European systems), or is the significance of private institutions in this part of Europe "a passing phase attributable to the special circumstances surrounding the transition from communist to postcommunist regimes," a response to particular political circumstances ie, an "internal phenomenon" (Scott, 2007, p. 309)? There is no final answer today; both demographics and politics will play their substantial roles in the next decade. The role of demographics is predictable, but the role of politics is not (Kwiek, 2013b). Poland, already experiencing severe demographic

\footnotetext{
2 Thus we do not analyze here those private higher education institutions which the OECD terms "government-dependent private institutions"; that is, by definition, those which receive from government agencies more than $50 \%$ of their core funding, or those whose staff are employed and paid by these agencies.
} 
shifts in higher education, and the fastest-aging society in the OECD area by 2025 , needs thoughtful policy responses under changing public-private dynamics. Demographic shifts are painful to both sectors; enrollments dwindled from about 2 million in 2005 to about 1.5 million in 2014. Emergent policies might use more market mechanisms in the public sector, more cross-sectoral competition, and more private funding in both public and private sectors. However, they might also merely follow declining demographics and current funding arrangements in the public sector (no fees for full-time students, despite recent failed attempts to introduce fees for full-time students studying a second field of study or longer than 5.5 years), and let the system be gradually remonopolized by the public sector. Depending on policy choices, both scenarios are possible. But the policy of no interference, known from the 1990s, seems more plausible today. A continuous increase of tax-based places in the public sector may lead to the ultimate demise (or semidemise) of the private sector, after a quarter of a century of its existence in Poland. Individual, institutional strategies for survival (which Teixeira and Amaral (2007) sought for Portuguese private higher education decline in the 2000s) do not suffice in the Polish context; large-scale changes in national funding architectures might slow down the process but would not change its direction. ${ }^{3}$ If the status quo is maintained, the contraction period (2005-25) will bring about the decline of the predominantly demand-absorbing private sector; when demand is over, the sector will finally shrink from more than one-third of enrollments in 2006-09, possibly to 10-12\% of enrollments in 2025, and from the ceiling of 330 private institutions in 2009 to about 60 within a decade, according to recent predictions of the Ministry of Science and Higher Education (MoSHE, 2012, p. 8).

\subsection{From the expanding privatized to the contracting publicly funded university}

Polish higher education has changed fundamentally since 1989, both quantitatively (participation rates, the number of students, faculty, and institutions) and qualitatively (regained institutional autonomy and academic freedom, shared governance,

\footnotetext{
${ }^{3}$ Major conclusions from research on Portuguese private higher education fit the Polish case perfectly. Major mechanisms in the emergence, growth, and public/private dynamics seem similar. One argument is that the private sector was a cheap solution to the expansion issue: "expansion based on private sources has made possible an increase in enrollment rates at minor cost to public finances" (Teixeira \& Amaral, 2001, p. 363). Another argument is about the limited intersectoral public-private competition: "the main public institutions ... compete among themselves for the best students, for research funds, and even for academic staff. ... In general, these [private sector] initiatives have been designed for short-term profit making rather than as sound academic and financial projects" (Teixeira \& Amaral, 2001, p. 370). Still another argument is about the demand, which exceeded supply: "for the new developing private sector, resources have not been scarce because demand has largely exceeded the available provision. This has meant that private institutions could do what they liked: and this they certainly did. ... Institutions have preferred to offer [a] low-quality, low-cost product in order to maximize short-term profits instead of aiming at a better product that in the long run would offer them better prospects of survival" (Teixeira \& Amaral, 2001, pp. 390-391). Finally, as in Poland, "costly or risky activities" were left to public institutions. For parallel discussions about Polish private higher education, see Kwiek (2010, 2012a, 2012b).
} 
emergent public-private duality, new competitive research funding regimes, and new fee regimes). The scope of changes and their speed are not easy to comprehend outside the context of the overall postcommunist transition to an open, market-driven economy, fully integrated with European Union (EU) economies. The gradual political, economic, and social integration of Poland with the EU has been accompanied by a deepening, gradual integration with Western European higher education and research systems, already involved in the deepened European integration processes (Kwiek \& Maassen, 2012; Maassen \& Olsen, 2007).

Polish higher education by 2005 became a dual (public-private), highly differentiated, strongly marketized, and hugely expanded system, with all the ensuing consequences of fast changes for both institutions and the academic profession. Since 1989, the system has witnessed a phenomenal rise in the number of public and private institutions, a rise and fall in the number of students (from 0.40 million in 1989 up to 1.95 million in 2006 and down to 1.82 million in 2010, and 1.55 million in 2013), as well as a rise in the number of doctoral students (from about 2000 in 1990 to about 43,400 in 2013) and in the number of academics (from 40,000 to 99,000 in the same period).

The emergence of the private higher education sector in the 1990s contributed to demand-absorbing growth, but the expansion occurred throughout the two sectors and throughout the two major modes of studies, full-time and part-time (Poland has the highest share of part-time students in Europe, 39.37\% in 2013, GUS, 2014, p. 61). The period of expansion can be viewed through the double matrix of two major dimensions: public and private sectors, and full-time and part-time modes of studies, or through a single matrix in which the major dimension is fees. The most prestigious first-choice positions have been free or tax-based places in the public sector; the second-choice positions have been fee-based places in the public sector and in the private sector.

Consequently, Polish students can be defined by the sectors they come from: public and private. But even more fundamentally, they can be defined as fee-paying and taxbased students. Fee-paying students are all students from the private sector (full-time and part-time) and all part-time students from the public sector. Tax-based students are all full-time students from the public sector. While according to the former distinction, $25.72 \%$ of students are enrolled in private institutions and $74.28 \%$ in public institutions (2013); according to the second distinction, less than half of all students, or $45.50 \%$, are fee-paying students. The first impact of the current powerful reversed demographic trend is seen through the stagnating, and then falling, share of fee-paying students in both sectors (combined) beginning in 2006. The total number of tax-based students have been increasing throughout the last decade, but only in the last five academic years (2009-13) did the share of tax-based students increase from $43.58 \%$ (2009) to $55.50 \%$ (2013) (GUS, 2014, p. 61). Under such declining demographics, the speed of the ongoing changes in student composition by sources of funding (and by sector) has been amazing; it has been a zero-sum game. In student numbers, public sector gains mean private sector losses.

The share of fee-paying students (that is, all students in the private sector and part-time students in the public sector) in the student body in the expansion period of 1990-2005 was high from a European comparative perspective (46.6\% in 1995, 
$62.8 \%$ in 2000, and $58.9 \%$ in 2005). In the contraction period, in 2006 and beyond, this share has been steadily declining, down to $44.50 \%$ in 2013. The Ministry expects it to be only 20\% in 2022 (MoSHE, 2012, p. 8). A set of figures below shows the ongoing changes in the contraction period in both sectors combined (Figs. 4.1-4.3), in the public sector (Fig. 4.4), and in the public sector (Fig. 4.5).

Against global trends in cost-sharing (increasing percentages of fee-paying students (see Johnstone and Marcucci (2010), Johnstone (2006), and Callender and Heller (2013)), the number of fee-paying students in Poland has been steadily decreasing, by almost $15 \%$ points in 2006-2013 (from $58.58 \%$ to $44.50 \%$ ). The new public-private dynamics puts the question of cost-sharing in a different context. The question of equitable access to higher education looks different when 6 in 10 students pay fees and different when it is only 4, and ultimately, 2 in 10 in the coming decade (MoSHE, 2012, p. 9). The changing public-private dynamics lead either to the refinement of arguments in favor of universal fees or to their different nature. The social experiment of high fees in England, unique in Europe, needs to be studied closely in Poland.

In the 1990s, when the first private institutions appeared throughout Central and Eastern Europe (see their "search for legitimacy" in Slantcheva and Levy, 2007), Polish higher education policy was focused mostly on educational expansion. Private (called "non-public" in legal terms) institutions in Poland and elsewhere in the region were mushrooming;

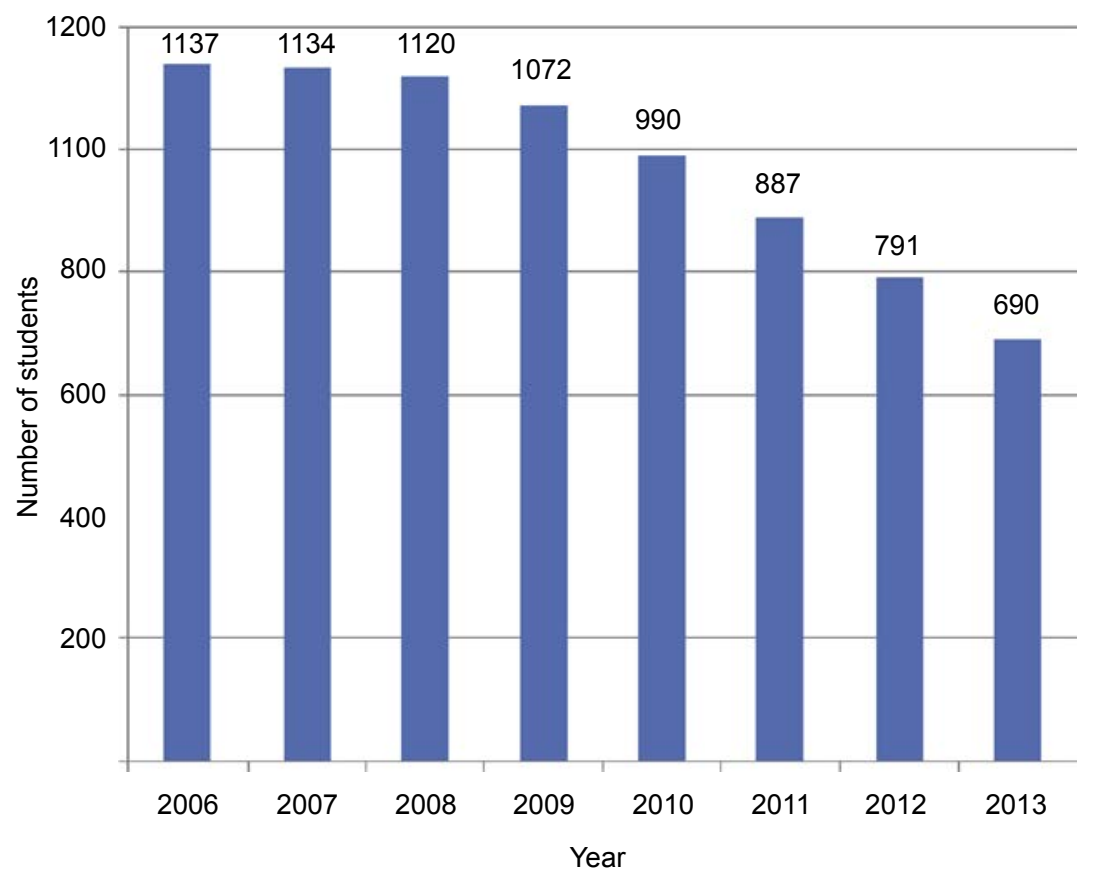

Figure 4.1 The number of fee-paying students in public and private sectors combined, 2006-13 (in thousands).

Own calculations based on GUS. (2014). Higher education institutions and their finances in 2013. Warsaw: GUS (Central Statistical Office) and its previous editions. 


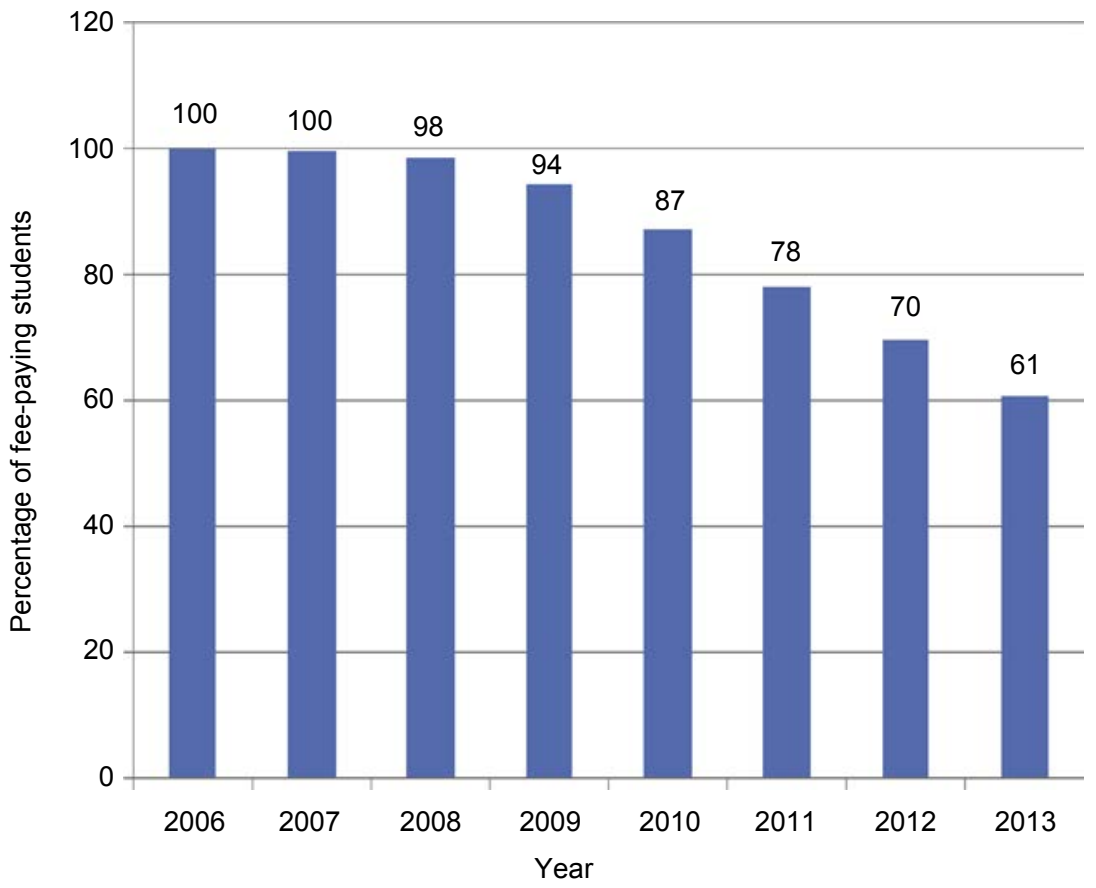

Figure 4.2 The change in the number of fee-paying students in both sectors combined, $2006-13(2006=100 \%)$.

Own calculations based on GUS. (2014). Higher education institutions and their finances in 2013. Warsaw: GUS (Central Statistical Office) and its previous editions.

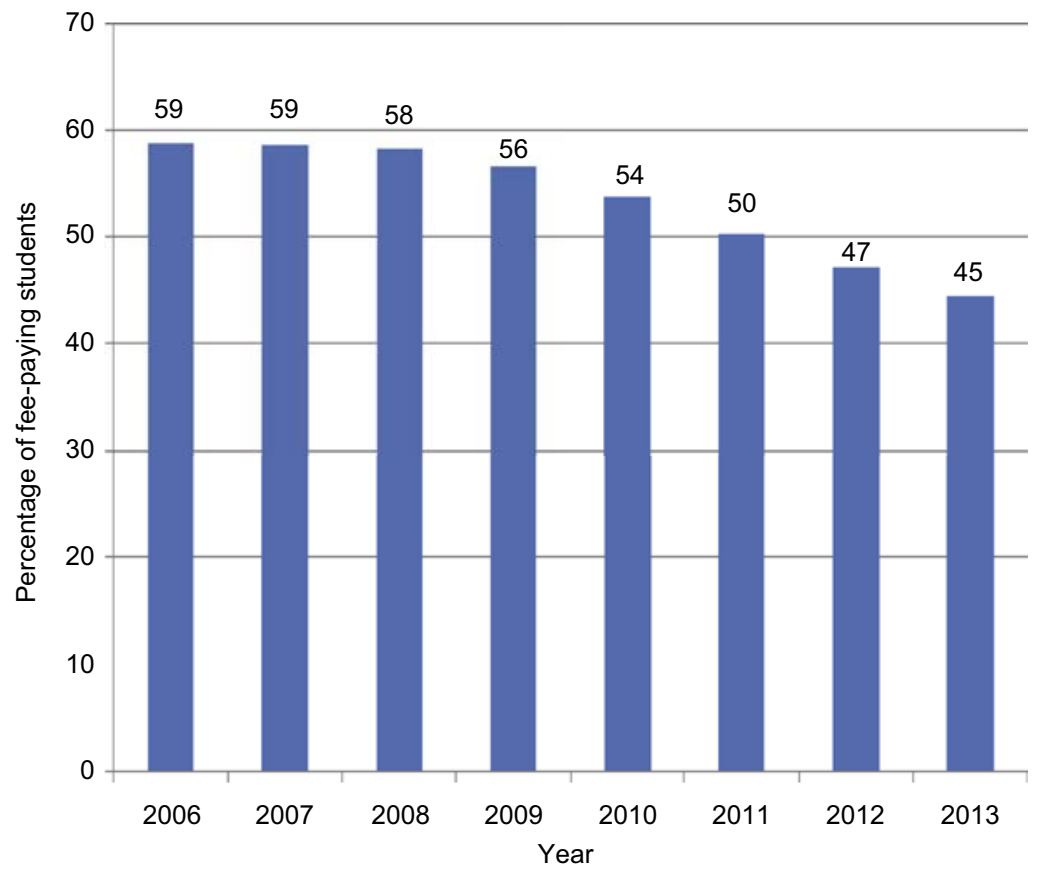

Figure 4.3 The share of fee-paying students in both sectors combined, 2006-13 (in \%). Own calculations based on GUS. (2014). Higher education institutions and their finances in 2013. Warsaw: GUS (Central Statistical Office) and its previous editions. 


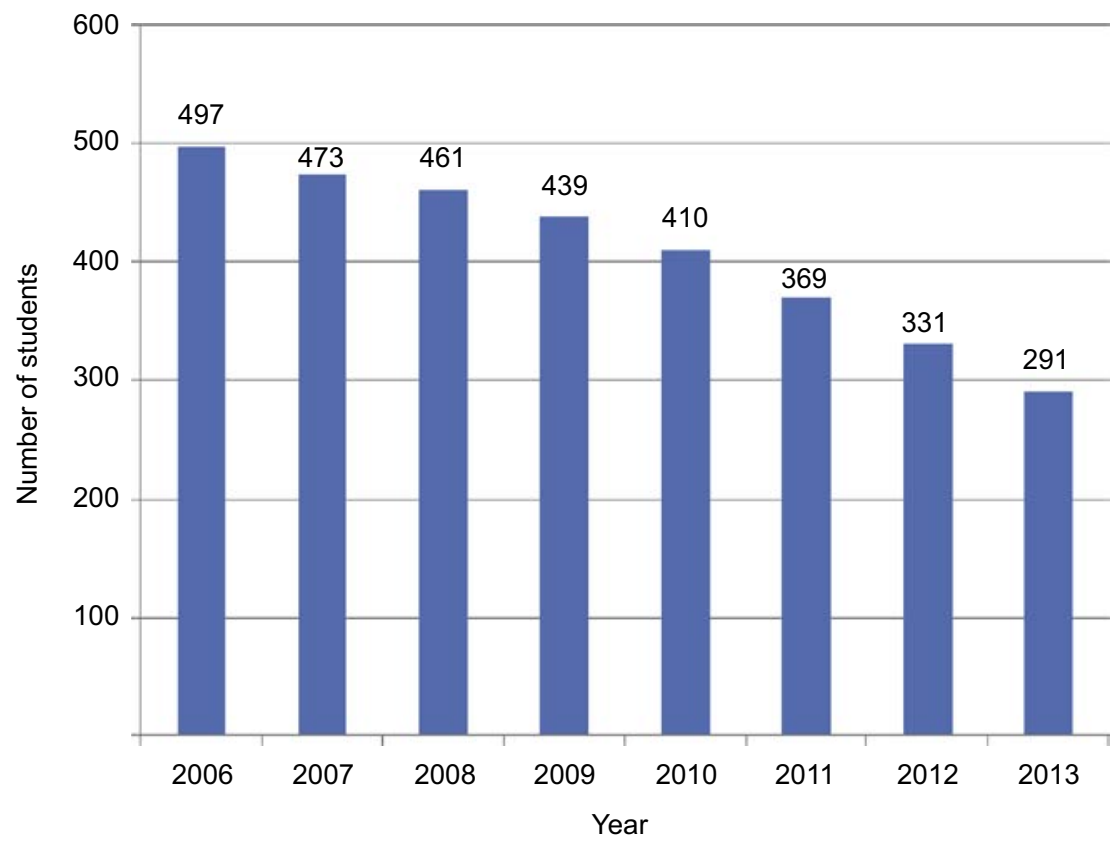

Figure 4.4 The number of fee-paying students in the public sector, 2006-13 (in thousands). Own calculations based on GUS. (2014). Higher education institutions and their finances in 2013. Warsaw: GUS (Central Statistical Office) and its previous editions.

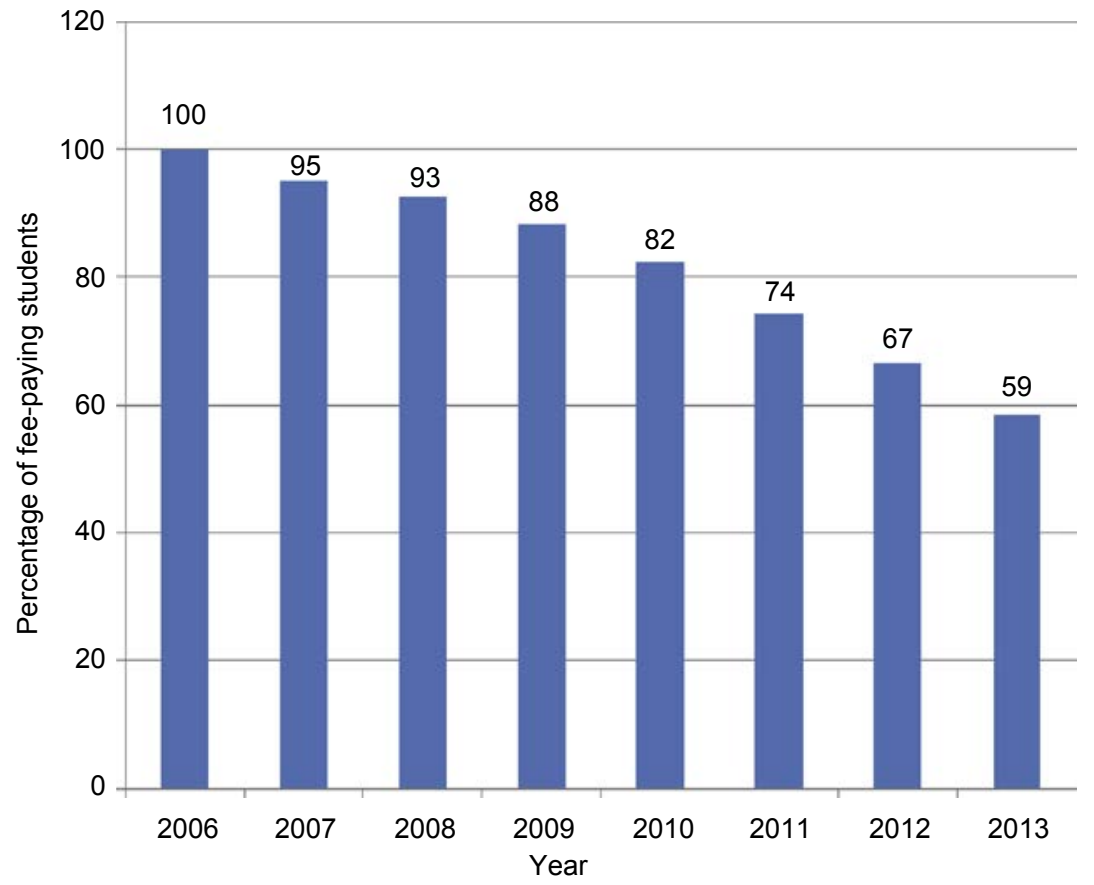

Figure 4.5 The change in the number of fee-paying students in the public sector, 2006-13 $(2006=100 \%)$.

Own calculations based on GUS. (2014). Higher education institutions and their finances in 2013. Warsaw: GUS (Central Statistical Office) and its previous editions. 
there were limited quality assurance mechanisms and accreditation procedures in place at the time. The first strong Polish Accreditation Commission, technically able to monitor teaching quality in private (as well as public) higher education was formed in 2002. The expansion of the system in the 1990s was closely linked to relaxed educational policy that encouraged external privatization (the emergence of new private providers) and internal privatization (the emergence of fee-based part-time studies in the nominally free, or taxbased, public sector; on the distinction, see Kwiek, 2010, 2013a).

As has been discussed elsewhere in more detail (Kwiek, 2013b), the upward trend was accompanied by increasing hierarchical differentiation: much of the growth was absorbed by public and private second-tier institutions, as well as by first-tier public institutions in their academically less demanding and less selective part-time studies. Expansion also took place predominantly in specific fields of study, such as, in particular, social sciences, economics, and law (see Figs. 4.6 and 4.7 below for the private sector, and Figs. 4.8 and 4.9 for both sectors combined). In the private sector, the share of students in these areas was $74.41 \%$ in 2000 , and then decreased, but is still about a half of all enrollments (49.04\% in 2013).

The expansion was financially supported by both public and private sources of funding. The inflow of public funding to the public sector in the expansion period was significant, but equally significant was the inflow of private funding from fees to both sectors. While the private sector is overwhelmingly reliant on tuition fees, the public sector during the peak of expansion (especially in 2000-05) was also heavily reliant

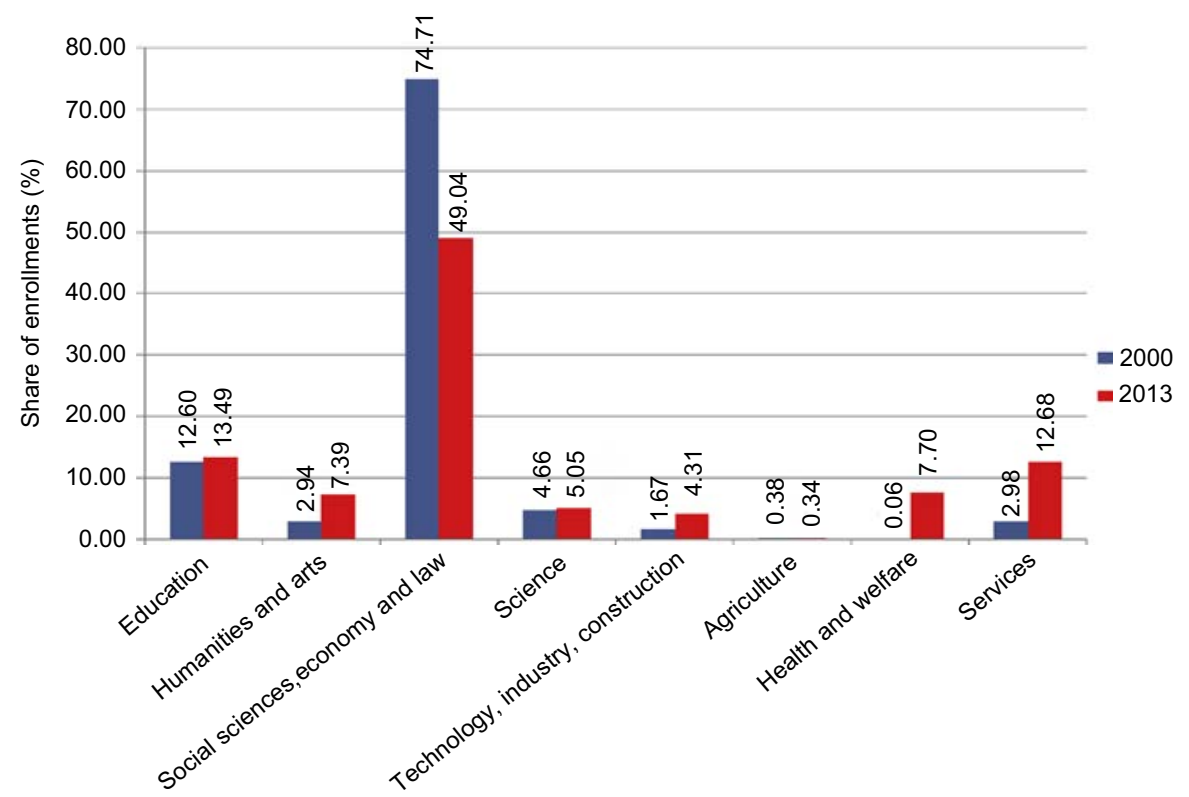

Figure 4.6 Share of enrollments by field of study in Poland, private sector, 2000-13 (in \%). GUS. (2014). Higher education institutions and their finances in 2013 (pp. 64-65). Warsaw: GUS (Central Statistical Office) and previous editions. 


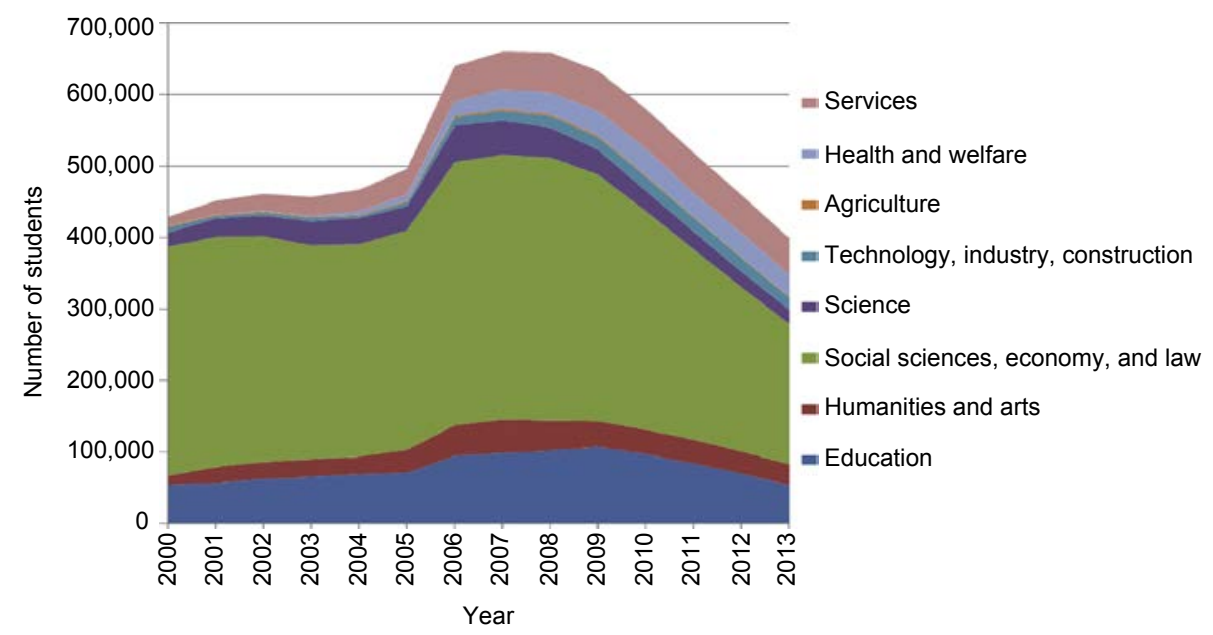

Figure 4.7 Enrollments by field of study in Poland, private sector, 2000-13.

GUS. (2014). Higher education institutions and their finances in 2013 (pp. 64-65). Warsaw: GUS (Central Statistical Office) and previous editions.

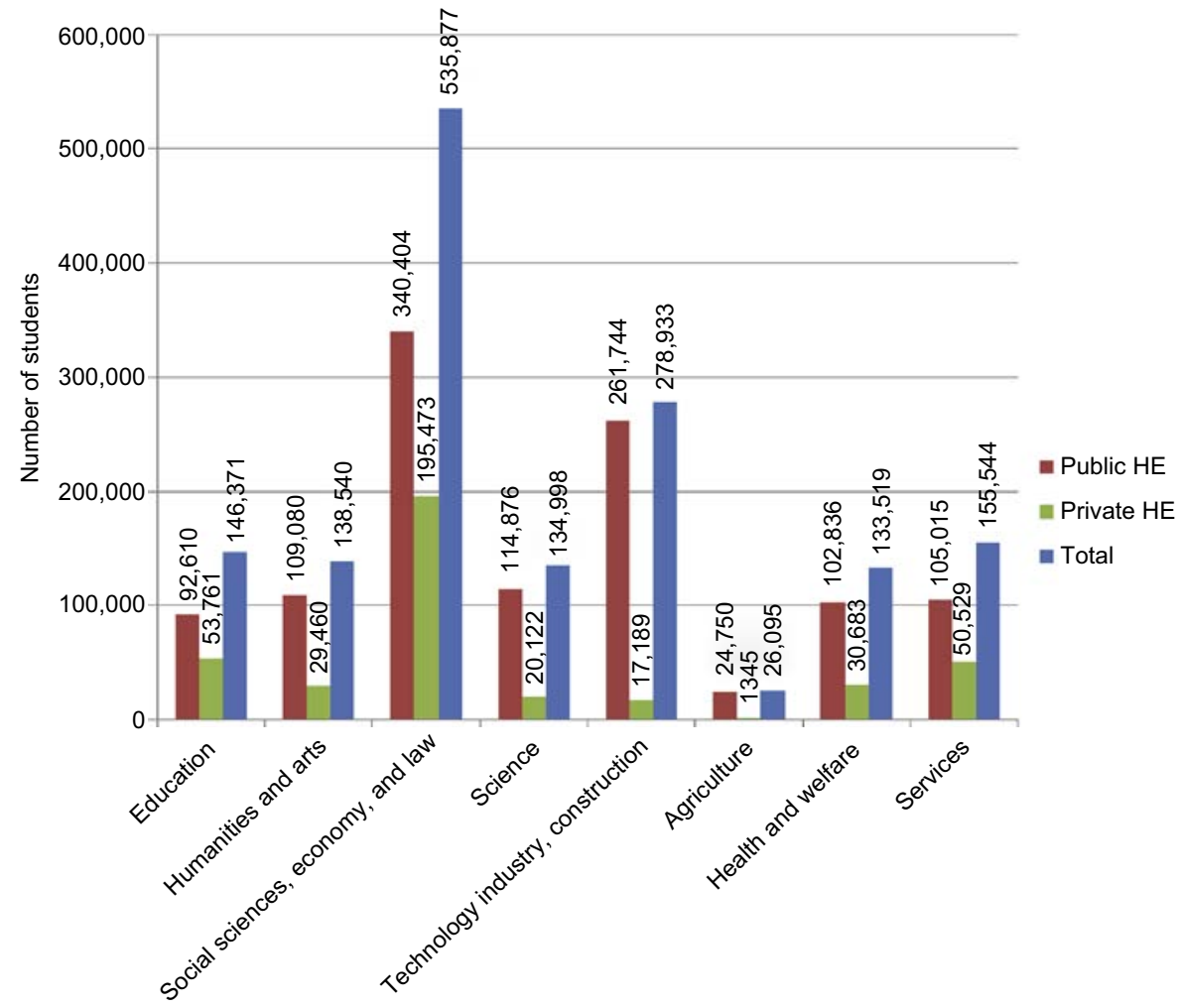

Figure 4.8 Enrollments by field of study in Poland, public and private sectors, 2013.

GUS. (2014). Higher education institutions and their finances in 2013 (pp. 64-65). Warsaw: GUS (Central Statistical Office). 


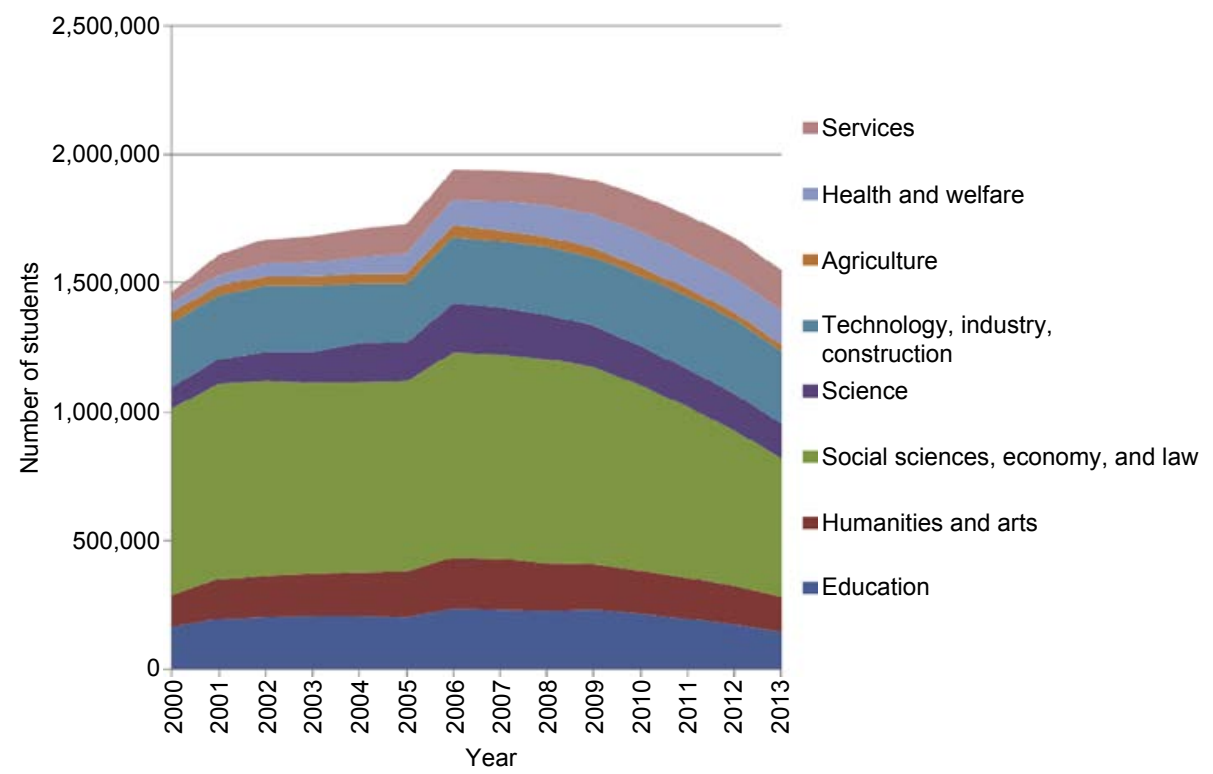

Figure 4.9 Enrollments by field of study in Poland, public and private sectors combined, 2000-13.

GUS. (2014). Higher education institutions and their finances in 2013 (pp. 64-65). Warsaw: GUS (Central Statistical Office) and previous editions.

on tuition fees from part-timers, which provided 16-20\% of its operating budget in that period. Then the share of funding from fees was decreasing year by year, both in the public system as a whole and in the budgets of individual institutions, including the two most prestigious, University of Warsaw and Jagiellonian University in Cracow.

While Polish higher education in 1970-90 could be termed unified (Meek, Goedegebuure, Kivinen, \& Rinne, 1996; Shavit et al., 2007), in the recent period of expansion (1990-2005) it moved from a unified to a diversified system. Under communism there was no inclination to encourage higher education expansion, either of existing elite universities or through the formation of new, especially nonuniversity institutions. The number of students in the two decades 1970-90 was strictly controlled by the state and, in general, did not increase. While Western European systems were already experiencing the processes of massification in the 1960, 1970 and 1980s, higher education in Central Europe was as elitist and inaccessible in 1990 as in past decades. One of the major reasons for the phenomenal growth of private higher education following the collapse of communism in 1989 in (some) Central European countries, and in Poland in particular, was the heavily restricted access to public higher education under communism combined with the new private sector employment opportunities. Increasing salaries in the emergent private sector, combined with increasing educational aspirations, gradually pushed ever more young people into higher education.

The processes of (internal and external) privatization are currently in retreat, though: we termed elsewhere the ongoing changes the "de-privatization" or "re-publicization" of higher education (Kwiek, 2015). Under declining demographics, the number of 


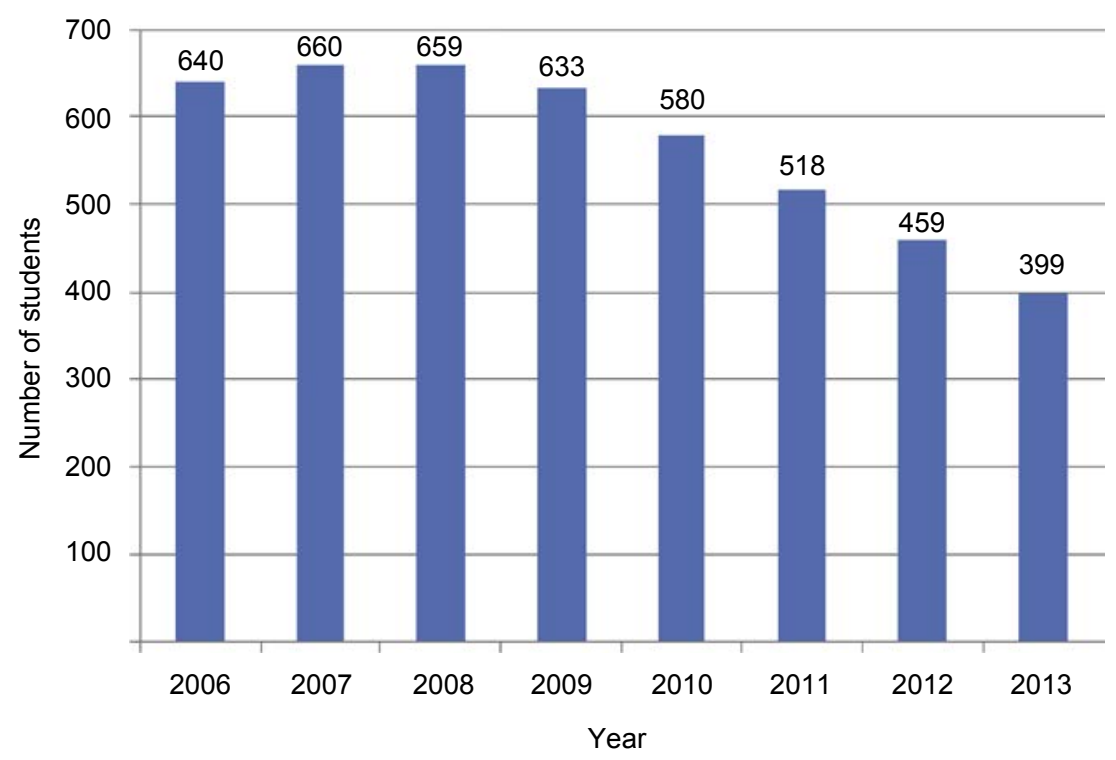

Figure 4.10 Enrollments in the private sector, 2006-13 (in thousands).

GUS. (2014). Higher education institutions and their finances in 2013 (p. 64). Warsaw: GUS (Central Statistical Office) and previous editions.

fee-paying students in the public sector decreased dramatically by $40 \%$ in the period 2005-13, as did the share of income from fee-paying students in the public sector, from $16.6 \%$ in 2005 to $10.6 \%$ in 2013 (GUS, 2014, pp. 181-184). The number of private institutions is only just beginning to decrease, and the number of mergers and acquisitions in the private sector is on the rise. Specifically, private sector enrollments have been shrinking dramatically, by almost $40 \%$ in the period 2007-13 (from 660,000 to 399,000 students, or by $39.45 \%$ ). Ministerial projections show that the number of institutions may shrink until 2020 by $80 \%$ (MoSHE, 2012, p. 9). The decline of the private sector is fundamental, and cannot be reversed: Poland will witness another decade of its gradual demise, especially that declining demographics is combined with an expanding pool of tax-free places in the public sector. The increasingly (internally and externally) privatized higher education of the expansion period is becoming ever more public, with an increasing reliance on public funding. De-privatization replaces privatization, against the global trends of increased privatization and cost-sharing in higher education. Changes in enrollments in the private sector in 2006-13 are presented below in Figs. 4.10 and 4.11.

Dramatically changing demographics is becoming the major parameter of higher education policy; enrollments, expected to fall from about 1.95 million students (2005) to about 1.2 million in 2025 , introduce new policy dilemmas. We expect public policy for higher education in times of expansion to be fundamentally different from public policy in times of contraction, the issue having been explored elsewhere in more detail (Kwiek, 2013b). Powerful demographic shifts may thoroughly change the structure of the system, and the remonopolization of the system by the public sector cannot 


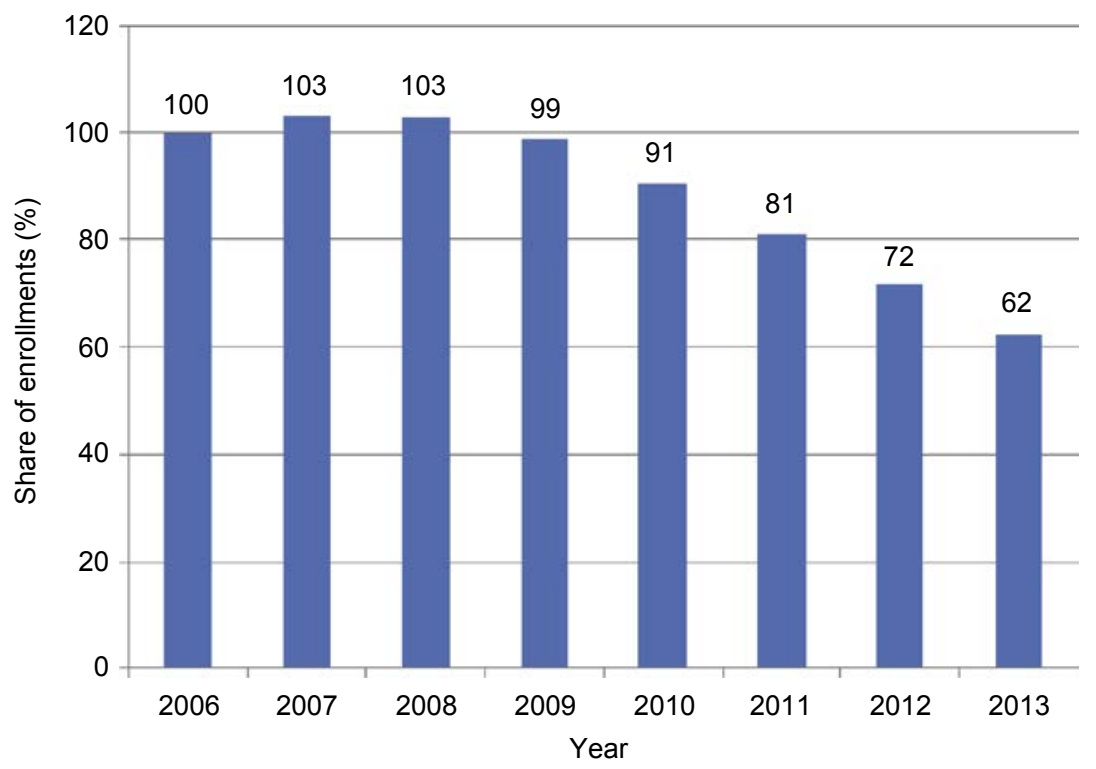

Figure 4.11 Enrollments in the private sector, 2006-13 $(2006=100 \%)$.

GUS. (2014). Higher education institutions and their finances in 2013 (p. 64). Warsaw: GUS (Central Statistical Office) and previous editions.

be excluded, due to the gradual (spread over the next decade) decline of the private sector. All public institutions and the surviving privates may be becoming isomorphic, aggressively client-seeking under declining demographics.

Possible policy interventions at the macro-level could be in the private sector only (public subsidization of teaching in the private sector), in the public sector only (introducing universal fees in the public sector), or in both sectors (a combination of both policy interventions). However, Poland does not seem to be politically prepared for the introduction of universal fees in the public sector or for the introduction of public subsidies in the private sector. Both might slow down the gradual disintegration processes of the private sector in the coming years, should the sector be deemed worthy of being supported by state interventions, which is not clear today.

\subsection{Higher education expansion and projections for the future: educational contraction and private higher education}

The expansion of the Polish higher system slowed down after 15 years (1990-2005) and since then, the system has been gradually contracting. Further powerful contraction is expected, as projected by scenarios for the years 2010-25 presented below. The processes of contraction have far-reaching consequences for the future differentiation 
of the system, public-private dynamics, and the future of private institutions. There are three interrelated dimensions relevant to a study of Polish private higher education:

- The complicated intersectoral public-private dynamics with one of the highest degrees of marketization in the system in Europe (an extraordinarily high share of fee-paying students with both the highest share of enrollments and the highest student numbers in the private sector in Europe).

- The most radical demographic changes projected for the next decade from among European Union countries, leading to OECD projections in which the number of students will go down from 1.82 million (2010) to 1.33 million (2020) to 1.17 million (2025).

- A changeable educational policy climate: the possibility of political decisions introducing universal tuition fees in the public sector and direct state subsidization of the private sector. (In the communist period of 1945-89 and ever since 1989, there were no fees for full-time students in the public sector, and in the last decade there was mostly indirect state subsidization of the private sector through state-subsidized student loans).

In vertically differentiated systems such as the Polish one, questions like "admissions to what," leading to "credentials from where," need to be asked. Two major types of institutions provide two major types of credentials: those from traditional metropolitan, elite public universities, with full-time modes of study, and those from all other types of institutions and modes of study (a part-time mode of study in the Polish context being much less academically demanding than a full-time mode).

In the first decade of the expansion (the 1990s), the difference between the two types of institutions and the two types of credentials was not an issue of public concern. Families with high socioeconomic capital, usually from the former class of the intelligentsia, who gradually turned into the new middle class of professionals, sent their children to the first type of institutions, as they did in the whole postwar period. The tax-based places in metropolitan elite institutions were scarce and available on rigid meritocratic selection criteria, though the number of tax-based places was increasing throughout the 1990s. However, elite metropolitan universities tried to retain their high quality of teaching in the times of ever increasing student numbers through channeling the newcomers, mostly from the lower socioeconomic classes, to their paid part-time study offers of considerably lower academic quality. Interestingly, for almost two decades (until a Diploma Supplement was introduced, related to the implementation of the requirements of the Bologna Process in European higher education), there was no trace in master's diplomas of whether the studies were fulltime or part-time. Both students and public institutions, for different reasons, were interested in blurring the difference between two types of graduates coming, from an academic standpoint, from clearly different study programs. Students were increasingly seeking credentials to be used in the labor market and willing to pay for their education, and public institutions were increasingly seeking additional revenues from part-time studies. Elite universities became as open to the newcomers as never before (Wasielewski, 2013); the share of students from lower socioeconomic classes in taxbased studies reached the $20 \%$ ceiling in the early 2000s, and in fee-based studies it was much higher. In particular, the private sector (first emergent and then consolidating) was completely open to new clientele, following open-door policies. Newcomers 
to the education sector after 1989, especially from the lower socioeconomic classes, went to new regional public universities, fee-based streams in elite metropolitan public universities, or to the emergent fee-based private sector.

The quality of higher education provided in both public and private institutions, and the differentiation of institutions and credentials, became a public issue only in the second decade of expansion, in the 2000s. The most valuable places-those in elite metropolitan public universities in full-time modes of study-were scarce and competitive. They were socially valuable not only because they were tax-based, but because they were academically demanding. All the other places, much less socially valuable from an overall perspective, and conceived of as much less socially valuable by the intelligentsia-turned-middle classes, were offered to all, in fee-based modes, throughout these two decades. Students, especially from part-time studies in both sectors, to a large extent could be described as academically adrift; "they might graduate, but they are failing to develop the higher-order cognitive skills that it is widely assumed college students should master" (as Arum \& Roksa, 2011, p. 121 put it in an American context).

During the expansion period of 1990-2005, higher education was both accessible and affordable, and the recognition of its differentiation by type of institution and by mode of studies was low. This nondifferentiation in the educational arena, paradoxically, seemed useful to all stakeholders: students and their parents, public and private institutions, as well as the state. The state was boasting ever-rising gross enrollment rates and the increasing education of the workforce; public institutions were offering part-time studies for fees and this noncore nonstate income played a powerful role in maintaining the morale of academics through increasing their university incomes. The stratification of the system increasingly became common knowledge and governed most student choices only in the second decade of the expansion when the labor market was saturated with new graduates (about 2 million in 1990-2003).

From a demographic perspective, the number of 19-year-olds was increasing throughout the 1990s and until 2002. Since then, the number has been decreasing, and according to demographic projections, it will be decreasing until 2022. In 2020, there will be about 360,000 of them, compared with about 612,000 back in 2005 and 534,000 back in 2010. Also, the pool of potential students (traditionally the 19-24 age bracket in Poland) will be steadily decreasing every year until 2020, from about 3.4 million in 2010 to about 2.3 million in 2020 (a decrease of $31 \%$ within a decade).

The future of private higher education in Poland (and the public-private dynamics in the context of a zero-sum game with a fixed pool of applicants) is linked to a demographic much stronger than in any other European Union country. Vincent-Lancrin, in his paper on the impact of demography on higher education systems (based on forward-looking quantitative scenarios), stressed the complexity of the relationship:

\footnotetext{
All things being equal, demography directly affects student enrolment in higher education because the size of younger age cohorts is a partial determinant of the number of students. ... If rates of entry to higher education, together with survival rates, the average length of courses and other student-related factors (age, etc.) remain unchanged, countries in which those cohorts decrease in size will
} 
normally experience a fall in their student enrolments. Yet the relationship between demography - or more specifically the size of the younger age cohorts - and higher education enrolment levels is a complex one.

Vincent-Lancrin (2008, p. 43).

Increases in rates of access or a change in the length of studies may offset decreases in cohort size. Studies can be made to last longer and access rates will depend on the eligibility rate and the proportion of those eligible who in fact enroll (different aspirations, and incentives, but also different numbers of places): "the actual proportion of entrants also depends, among other things, on the cost of higher education, the financial pressures confronting those otherwise eligible, [the] pecuniary (and non-pecuniary) advantages that they hope to gain from higher education and the length of their studies from an opportunity cost perspective." Student enrollment levels lag behind changes in the size of younger age cohorts, as the demographic shift takes several years to be noticeable (Vincent-Lancrin, 2008, p. 44).

The author presents two scenarios: the "status quo scenario" and the "trend scenario" for OECD countries for the years 2015, 2020, and 2025. In the first scenario, entry rates remain at the 2004 level; in the second, entry rates are extrapolated linearly on the basis of the trends in each country between 2000 and 2004. The fall in enrollment levels in Poland is the highest in the European Union, and comparable in the OECD area only with Korea and Japan. In the first scenario, enrollments in 2025 are expected to fall to $55 \%$ of 2005 levels, or dwindle by almost a million students (a fall of 947,000 students). To illustrate the gravity of the challenge; in the EU, only Spain and Germany can expect numerical decreases of more than 200,000 students (Spain by 342,000 and Germany by 209,000 , or three and five times less than in Poland). In the second scenario, enrollments in Poland in 2025 are expected to fall to $65 \%$ of 2005 levels, or dwindle by almost 800,000 students $(775,000)$. In Spain, the second highest after Poland, the decreases are expected to be five times smaller (165,000 students).

In countries in which higher education is predominantly funded through private expenditure, such as Japan and Korea, and where there is a combination of aging populations, low birth rates and the saturation of higher education markets following the completion of universal higher education, the relationship between demography and higher education enrollments goes in both directions:

Ironically, the sustained low birth rate in both nations is often attributed to the high cost of education which parents are expected to bear. In these circumstances, financial issues in higher education require special attention not only to maintain universal access but also to prevent further demographic decline.

Yonezawa \& $\operatorname{Kim}(2008, p$. 213).

In this context, cost-sharing mechanisms may play different roles in expanding systems than in contracting systems where birth rates are already the lowest in Europe, as in Poland (see Johnstone and Marcucci (2010) and Johnstone (2006) for a comprehensive summary of the rationale for cost-sharing). There may be a vicious circle of expensive higher education (by comparative standards as well as for individuals, both before and after the introduction of cost-sharing mechanisms) and declining birth rates 
for fear of even higher private educational expenditures in the future combined with an awareness of the social necessity to cover them in mass or universal systems.

In Poland, the 2000-04 period taken as a reference period for OECD projections was a period of rapid growth, but the growth rate has not reemerged in subsequent years, as the higher education market seems to be already saturated and the pool of applicants has been decreasing for demographic reasons. The difference for Poland between the two scenarios, from a qualitative perspective, is marginal, and if any later period (eg, 2004-08) was used as the reference period for projecting the trend in enrollments, it would be even smaller. In both scenarios the Polish case is unprecedented in the European Union, though.

In the present chapter, we consider the above OECD status quo scenario as more probable than the trend scenario in the Polish case, and we further develop it adding a political dimension. The reason to add politics is that the laws on higher education and other accompanying laws have been undergoing substantial transformations in Poland in 2008-12, and the major political issue relating to the future of the private sector and of the public/private dynamics is the possibility of universal tuition fees being introduced in the public sector.

Therefore, we assume here three basic scenarios, which relate demography with public/private dynamics (see OECD (2006) for the idea of scenarios in education). From the supply-side, three scenarios are possible:

- enrollments in full-time programs in the public sector will remain at current levels;

- enrollments will decrease proportionately in both sectors and both modes of study (full-time, part-time) due to declining demographics and

- enrollments in full-time programs in the public sector will increase (if the number of places increases by a mere $2 \%$, which is legally allowed for in the next few years, every year between 2013 and 2020, the public sector will be offering more than one million places by the end of the decade and these are "first-choice places").

In the first scenario, enrollments in full-time study programs in the public sector will remain stable in 2020 (about 850,000 students, as in 2010); in the second scenario, based on demographic projections, they will be about 550,000 students and in the third scenario, they will exceed 1,000,000 students. Consequently, in the first scenario, the private sector can expect about 250,000 students; in the second, about 450,000 students and in the third, only 100,000 or less. These are very general approximations. So far, detailed trend data on the distribution of first-year enrollments between the two sectors and between tax-based and fee-based places in both sectors support the third scenario, especially that the Polish Constitutional Court has decided (June 2014) that charging fees in the public sector for full-time studies in the case of a second field of study is unconstitutional. The first attempt to introduce fees for no more than $10 \%$ of students (in 2012), a testing ground before introducing universal fees for all students and an important part of ongoing funding reforms, has failed. The chances to introduce fees in the coming years are even lower; the budget pressures are lower as the system has been contracting (Polish reforms in the light of institutional theory, see Kwiek, 2016).

The policy conclusions are surprising: in fact, the biggest private higher education system in Europe ("independent private" in OECD terms, fee-based in practical terms) is heavily dependent for its survival on a change in higher education financing, 
namely, the introduction of universal fees in its competing public sector. It is possible that it is only the (rather improbable) introduction of universal fees in the public sector that could stop the gradual demise of the greater part of the private sector, with studying in the fee-based private sector currently being clearly a second choice for secondary school graduates. Public subsidization of full-time students in the private sector can be viewed as a half-measure only: in 2012, there were only 83,700 full-time students in the private sector (or a mere 18.2\%). Even if all full-time students are publicly supported, the remaining $82 \%$ of private sector students will not be.

If universal fees will not be introduced in this decade, which is very probable, the private sector will be heavily reduced in size. Maintaining the tax-based public sector under declining demographics is a disaster for the private sector, unless there are mergers between both private institutions and between public and private institutions, envisaged in the new law of March 2011. Consequently, lobbying for the introduction of universal fees in the public sector is the most effective survival strategy for the private sector in the years to come. Individual private institutions' strategies count much less than macro-level changes in funding mechanisms for public institutions.

Possible policy interventions can be the public subsidization of teaching in the private sector, introducing universal fees in the public sector, or a combination of both policy interventions. The segment of higher education with a strong interest in new policy choices is the private sector, expected to be desperately seeking survival strategies at the macro-level of national policies. What seems theoretically possible may be politically complicated; lobbying for the two policy choices is in progress. Given the stability of demographic factors, the unstable, unpredictable political factors are therefore extremely important for the higher education system as a whole and for the future of Polish private higher education.

The Polish private sector is already declining and the public-private dynamics are already changing and expected to change much more fundamentally in the coming years, as seen in Figs. 4.12 and 4.13.

Surprisingly, and against two powerful global trends of private sector growth (Levy, 2009) and cost-sharing in public sector funding (Callender \& Heller, 2013; Johnstone, 2006; Johnstone \& Marcucci 2010) in postmassified or universal systems, the Polish dual public-private system is increasingly based on public institutions and their taxbased students. In financial terms, the inflow of fees to the system as a whole, and to both the public and the private sector separately, has also been falling since 2007, and is expected to fall further in the next decade.

The changing share in enrollments over time in the two sectors is U-shaped for the public sector and inverted U-shaped for the private sector, as shown in Fig. 4.13. The processes of the de-privatization of the system, after almost two decades of ever-growing privatization, also denote the parallel processes of the remonopolization of the system by the public sector (which would be a return to a standard Western European pattern in which the role of the private sector is marginal, Western Europe being "one of the last hold-outs of free higher education" from a global perspective, Marcucci (2013)).

In the next decade, the system may be systematically returning to the status quo in which public institutions are in a near-monopolistic position (which means more public-private intersectoral homogenization), but they will be forced to differ more 


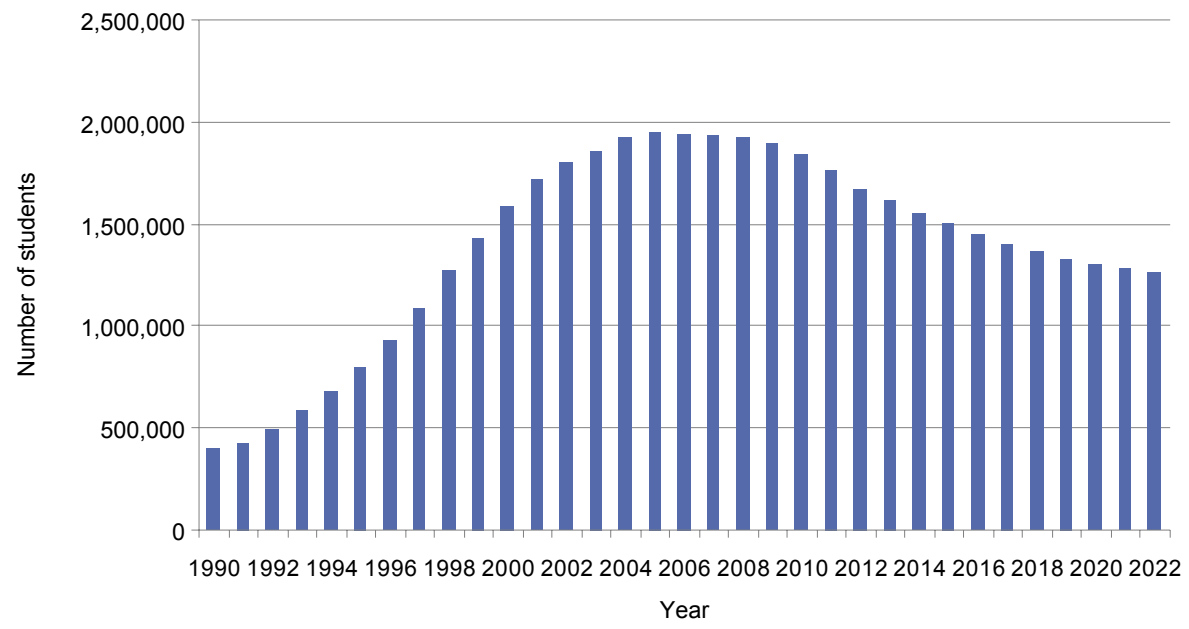

Figure 4.12 Changes in enrollments, 1990-2022 (2014-22 projections by the Ministry of Science and Higher Education).

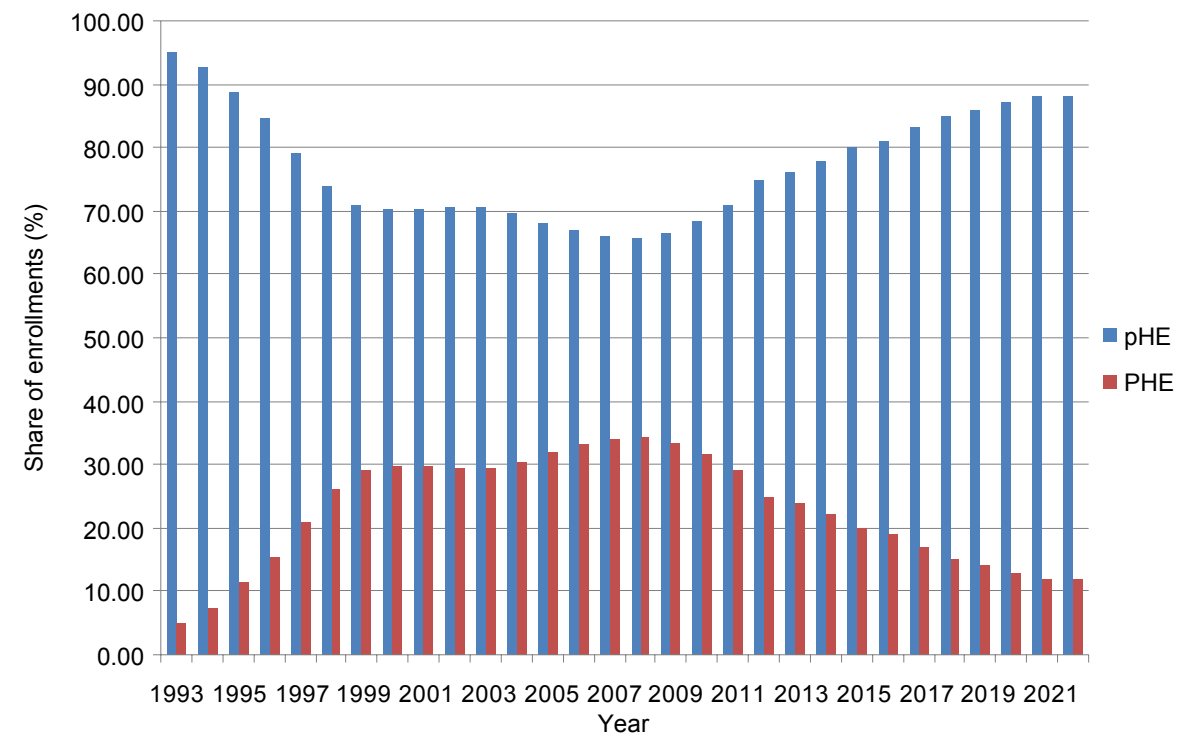

Figure 4.13 Changes in the share of enrollments, by sector (pHE - public higher education, PHE - private higher education), in percent (2014-22 projections by the Ministry of Science and Higher Education).

in their educational offers than ever before (which means more public-public and private-private intrasectoral differentiation). The gradual decline of the private sector is thus inevitably leading to the hegemony of the public sector. In all probability, it is a case of tertium non datur (although the history of higher education research tends to show that the field should strongly avoid large-scale and long-term predictions). 
The decline of private higher education is a rare theme in scholarly literature, as it is a rare phenomenon from a global perspective (Romania being another example, see Curaj, Deca, and Egron-Polak (2015)). But it is also rare for universal higher education systems (in Martin Trow's terms: gross enrollment rates exceeding 50\%, see Trow (2007)) to be contracting, as is the case in Poland. As Levy stresses,

\begin{abstract}
Many types of private higher education do decline and for various reasons. Yet, private higher education grows significantly despite all the negative factors identified. The overall private higher education decrease almost always refers to public-and private-sectors shares, not absolute enrollments. Even proportional decline in the private sector applies only to a minority of countries. The most vulnerable private higher education is the demand-absorbing type, which underscores that all parts of the sector do not face constant vulnerability.
\end{abstract} Levy (2010, pp. 11-12).

Poland (together with several other postcommunist European countries) is exceptional from a global perspective; both private shares in enrollments and also absolute enrollments in the private sector have been decreasing over the last 5 years. The private higher education sector may expect to enroll still fewer students every year, and for a system in which there are still 283 (2015) private institutions, it is an enormous institutional funding challenge. The demographic shift in Poland creates a major institutional funding challenge to all public institutions and introduces fierce competition among them, but for private institutions, it may be a life or death challenge. As a recent (2011) study by the national Institute for Educational Research (IBE, 2011, p. 110) points out, "it has to be assumed that a part of the newly created private institutions, of relatively poor educational offer, opened to meet the demand from the generation from the $1980 \mathrm{~s} \ldots$ will not be able to survive" (IBE, 2011, p. 110). A single survival strategy suggested by the Institute is the change of offer from higher education to adult education. Similarly, Ireneusz Białecki and Małgorzata Dąbrowa-Szefler (2009, p. 194) stress that demographic trends represent "a clear danger, above all for the financially weaker and poorer-quality fee-financed private HEIs." These findings are consistent with Levy's global conclusions about private higher education (2011, p. 5): "Much PHE has not had to offer very much, other than access and the prospect or hope of a degree. Logically, then, it is the demand-absorbing subsector of PHE that is most vulnerable when demands slows." But, at the same time, the trend will affect each institution separately, and, consistent with what Arthur Levine et al. wrote about the demographic challenges of the 1990s in American higher education, it is important to recognize that each college and university can determine its own future: "Every college in America is facing a somewhat different set of demographic circumstances. Each has the ability to do nothing, to hope for serendipity, or to shape tomorrow. The choice is entirely theirs" (Levine, 1990, p. 180).

In Poland, the current and projected decline is fundamental rather than limited in duration. It is unclear to what extent Poland is politically prepared for the introduction of universal fees in the public sector or for the introduction of subsidies in the private sector. It is also unclear to what extent the survival problem of the private sector will become a major policy problem to be solved by politicians. The introduction of universal fees may also be politically difficult in a much-felt climate of economic crisis in Europe. 
Expansion in Poland in both the public and private sectors was classically demanddriven: students and their families demanded more access to higher education following the collapse of communism, and their demand was being increasingly met. Higher education was no longer strictly rationed by the state, and the processes of massification were fueled by both sectors and both modes of study. Both sectors, at the same time, were strongly client-seeking in the times of expansion; but the question is to what extent client-seeking behaviors may be even more pronounced in the times of contraction, with far-reaching consequences for admissions criteria and selectivity.

\begin{abstract}
Clearly, the imperatives of client-seeking and status-seeking behaviors conflict with one another. Client-seeking implies low admissions criteria while statusseeking implies fewer clients than could otherwise be admitted. The conflict is often resolved through the differentiation of a status-seeking first tier of institutions and a client-seeking second tier, which is less selective and enjoys lower prestige. Thus, we expect to find greater enrolment rates and more institutional differentiation in market systems than in state-funded systems.
\end{abstract}

Arum et al. (2007, p. 8).

The Polish system is more market-like than most state-funded European systems but also much more state-funded than most global market-funded systems, such as the United States, Korea, or Japan. The increasing stratification of higher education institutions along client-seeking and prestige-seeking lines is a discernible process in times of system expansion. Most private institutions were more client-seeking than most public institutions, and both public, in their part-time studies, and private institutions were clearly focused on income-generation from fees. What will happen to these processes in times of the system contraction? All institutions, public (elite and regional) and private (both semielite and demand-absorbing), might potentially be forced to become increasingly client-seeking (with perhaps no significant difference whether the clients will be tax-based students funded by the state or self-funded fee-based students, no matter whether universal fees in the public sector are finally introduced in the coming decade or not). The introduction of universal tuition fees in the public sector, not attempted so far except for a test regarding a second field of studies, may fundamentally change the intersectoral dynamics in the system, eg, allow a higher proportion of private institutions to survive than otherwise would in a landscape with a tax-based public sector, but in the context of demographic decline, this does not have to contribute to the maintenance of the differentiation between client-seeking and status-seeking institutions. Both sectors may find it necessary to become as aggressively client-seeking as the private sector was ever since 1989.

It can be assumed that in contracting systems, the selectivity of all institutions, including elite and regional, semielite and demand-absorbing, in both the public and private sectors, can be expected to decrease over time. Admissions criteria can be expected to be less stringent, and access for candidates from lower socioeconomic classes to institutions that are highly selective today may be increasingly less based on meritocratic criteria. The metropolitan elite public universities may be expected to become more accessible to all social strata if their current capacities (human resources and infrastructure) are to be maintained. To maintain their current levels of selectivity, they would have to decrease their capacities as contraction processes progress in the next 15 years. 
From a political economy perspective, large-scale cuts in jobs in public higher education leading to a contraction in the public segment of the system are conceivable, but probably not in the coming decade. There seems to be no political will to decrease the pool of academics in this sector (see a synopsis of two decades of changes in Polish higher education in Kwiek (2014) and a European context in Kwiek (2003, 2009a, 2009b)).

Standard supply-side solutions for private providers in a contraction era could potentially be the provision of high-quality, socially recognized, and labor-market rewarded education. But the policy of noninterference and loose governmental control in the 1990s contributed to low competitiveness and low social recognition of the private sector vis-à-vis the public sector. A handful of exceptions (10-20 private institutions mostly located in Warsaw, the capital city, which could be called, following Levy, 2009; "semielite" see also Levy, 1986b) does not make a dramatic difference but needs to be noted.

Since demographic trends cannot be altered within a decade, the private sector is seeking to redefine national higher education funding architectures. In the good times of ever-increasing student numbers, the independence of the private sector from the state was key. Today, targeted state interference (the introduction of universal fees in the public sector or of state subsidies for teaching in the private sector, based, for instance, on competitive bids announced for various fields of study, periodically announced by the Ministry) seems the only long-term policy solution for the majority of privates. Still, the question is whether the subsidization of full-time students in the private sector, as a policy option, would dramatically change the future of private providers. The higher education market is increasingly a "prestige market" or a "positional market" and credentials, as well as the jobs and incomes these credentials lead to, are "positional goods" (see Brown, Lauder, and Ashton (2011), p. 136, Hirsch (1976), pp. 59-52, Frank (1985), pp. 7-8, and especially Marginson (1997), pp. 38-46). As elsewhere in Europe, prestige comes from traditional elite public universities.

Recent policy proposals (2011-13) seem to indicate a possible change in policy patterns in financing higher education. Following Levy's typology of public/private mixes in higher education systems (Levy, 1986a), they might indicate a policy move toward the homogenization of the two sectors. However, the road to what is termed in official documents of the Polish rectors' conference "the convergence of the two sectors" (see Woźnicki (2013)) is a long and uncertain one. The idea of public funding for both sectors, and universal fees in both sectors for all students, has been fervently discussed in the last 5 years, and this convergence does not seem to be any closer.

Private-public blends involve a number of important questions: a single sector or a dual one; if a single sector, statist or public-autonomous; if dual sectors, homogenized or distinctive and if distinctive, minority private or majority private? (Levy, 1986a, p. 198). The policy move suggested by the idea of the convergence of the two sectors in this typology, would be from the fourth pattern (dual, distinctive higher education sectors: smaller private sector funded privately, larger public sector funded publicly) or the third pattern (dual, homogenized higher education sectors: minority private sector, similar funding for each sector. Levy's first and second patterns refer to single systems, with no private sectors).

The policy debates about private-public financing emerging in Poland today are not historically or geographically unique. Levy identified three major policy debates in his fourth pattern of financing: the first concerns the very growth of private institutions, the second concerns whether new private sectors should receive public funds, 
and the third policy debate concerns tuition in the public sector. While in the 1990s, the debate about growth dominated in Poland, the 2010s can be expected to be dominated by debates about fees and public subsidies. In a highly centralized system, with a long tradition of strong government influence on public policy in higher education, the answers to both the fees and subsidies debates are strictly political.

The fall in enrollment levels in Poland is projected to be one of the highest in Europe, and comparable only with other postcommunist countries: Bulgaria, Romania, Slovakia, Estonia, Lithuania, and Latvia. According to several consistent enrollment scenarios based on national statistical data (such as eg, Antonowicz and Godlewski (2011, pp. 10-14), Ernst and Young (2010, p. 20), IBE (2011, pp. 110-11), Vincent-Lancrin (2008, p. 45)) enrollments in Poland in 2025 are expected to fall to 55-65\% of 2005 levels. In Western Europe, only Spain and Germany can expect numerical decreases of more than 200,000 students by 2025 (Vincent-Lancrin, 2008, pp. 49-51). Certainly, as Easterlin (1989, p. 138) confirmed in the US context, there is an "inverse association between college enrollment rates and the size of the college-age population" (and what Frances terms "the cohort effect," Frances, 1989, p. 143); "enrollment rates, in fact, partly depend on the size of the college-age population - other things remaining constant, at the aggregate level a larger college-age population makes for lower enrollment rates, while a smaller college-age population makes for higher rates" (Easterlin, 1989, p. 137). Demographic factors need to be combined with social, economic, and public policy related factors in any meaningful projections for the future.

\subsection{Conclusion}

The Polish case study is important for several reasons: the public-private dynamics are rapidly changing in a system which has the highest enrollments in the private sector in the European Union today. In the global context of expanding higher education systems, there are several systems in Central and Eastern Europe, and Poland is the biggest of them, which are actually contracting. Their contraction is fundamental and rooted in declining demographics. In the global (rather than European) context of increasing reliance on cost-sharing mechanisms and on the private sector growth paradigm in university funding, the Polish system seems to be moving in the opposite direction: global trends toward privatization can be juxtaposed with the Polish countertrend toward deprivatization. The number of private institutions is decreasing and is expected to decrease much further; the share of private sector enrollments is decreasing and is also expected to decrease much further, as is the number of private sector students. Furthermore, the number of tax-based places in the public sector is on the rise, and income from fees (charged to part-timers only) has been steadily declining. To put it in a nutshell, there are ever more public sector students compared with private sector students, and ever more public revenues compared with private revenues. The number of private providers is shrinking and the number of fee-paying students in the system as a whole is shrinking too. Poland is the most vivid example in Europe regarding the combined impact of demographic and political factors on public-private dynamics in higher education.

After a quarter of a century, declining demographics is transforming the growth of the private sector into a gradual decline, and the general trend of privatization in 
the expansion period into a general trend of de-privatization in a contraction period. However, as we higher education researchers know, any definite conclusions and large-scale predictions should be avoided, as the number of "known unknowns" and "unknown unknowns" in higher education is unlimited.

\section{Acknowledgments}

The author gratefully acknowledges the support of the National Research Council (NCN) through its MAESTRO grant DEC-2011/02/A/HS6/00183 (2012-17). My approach to the public-private dynamics in higher education is rooted in Daniel C. Levy's PROPHE research program (SUNY-Albany, USA), and my exchanges with Dan over the last ten years, on and off. My huge debt of gratitude goes to him. All errors and mistakes are certainly mine, though.

\section{References}

Antonowicz, D., \& Godlewski, B. (2011). Demograficzne tsunami. Raport Instytutu Sokratesa na temat wptywu zmian demograficznych na szkolnictwo wyższe do 2020 roku. Warsaw: Instytut Sokratesa.

Arum, R., \& Roksa, J. (2011). Academically adrift: Limited learning on college campuses. Chicago and London: The University of Chicago Press.

Arum, R., Gamoran, A., \& Shavit, Y. (2007). More inclusion than diversion: expansion, differentiation, and market structure in higher education. In: Y. Shavit, R. Arum, A. Gamoran (Eds.), Stratification in Higher Education: A Comparative Study. Stanford: Stanford University Press.

Bialecki, I., \& Dąbrowa-Szefler, M. (2009). Polish higher education in transition: between policy making and autonomy. In D. Palfreyman, \& D. T. Tapper (Eds.), Structuring mass higher education: The role of elite institutions. London: Routledge.

Brown, P., Lauder, H., \& Ashton, D. (2011). The global auction: The broken promises of education, jobs and incomes. New York: Oxford University Press.

Callender, C., \& Heller, D. E. (2013). Student financing of higher education: A comparative perspective. London: Routledge.

Curaj, A., Deca, L., \& Egron-Polak, E. (Eds.). (2015). Higher education reforms in Romania: Between the bologna process and national challenges. Dordrecht: Springer.

Easterlin, R. A. (1989). Demography is not destiny in higher education. In A. Levine, \& Associates (Eds.), Shaping higher education future: Demographic realities and opportunities, 1990-2000 (pp. 135-141). San Francisco: Jossey-Bass Publishers.

Ernst, \& Young. (2010). Strategia rozwoju szkolnictwa wyzszego w Polsce do 2020 roku. Warsaw: Ernst and Young.

Frances, C. (1989). Uses and misuses of demographic projections: lessons for the 1990s. In A. Levine, \& Associates (Eds.), Shaping higher education future: Demographic realities and opportunities, 1990-2000. San Francisco: Jossey-Bass Publishers.

Frank, R. H. (1985). Choosing the right pond. Human behavior and the quest for status. Oxford: Oxford UP.

Fried, J., Glass, A., \& Baumgartl, B. (2007). Shades of privateness: non-public higher education in Europe. In P. J. Wells, J. Sadlak, \& L. Vlasceanu (Eds.), The rising role and relevance of private higher education in Europe. Bucharest: UNESCO-CEPES.

GUS. (2014). Higher education institutions and their finances in 2013. Warsaw: GUS (Central Statistical Office). 
Hirsch, F. (1976). Social limits to growth. Cambridge: Harvard UP.

IBE. (2011). Spoleczenstwo w drodze do wiedzy Raport o stanie edukacji 2010. Warsaw: Instytut Badan Edukacyjnych.

Johnstone, D. B. (2006). Financing higher education. Cost-sharing in international perspective. Boston: CIHE.

Johnstone, D. B., \& Marcucci, P. (2010). Financing higher education worldwide. Who pays? who should pay? Baltimore: The Johns Hopkins University Press.

Kwiek, M. (2003). The state, the market and higher education. Challenges for the new century. In M. Kwiek (Ed.), The university, globalization, Central Europe. Frankfurt and New York: Peter Lang.

Kwiek, M. (2009a). The changing attractiveness of European higher education: current developments, future challenges, and major policy issues. In B. Kehm, J. Huisman, \& B. Stensaker (Eds.), The European higher education area: Perspectives on a moving target. Rotterdam: Sense.

Kwiek, M. (2009b). Globalisation: re-reading its impact on the nation-state, the university, and educational policies in Europe. In M. Simons, M. Olssen, \& M. E. Peters (Eds.), Re-reading education policies. A handbook studying the policy agenda of the 21st century. Rotterdam: Sense.

Kwiek, M. (2010). Transformacje uniwersytetu. Zmiany instytucjonalne i ewolucje polityki edukacyjnej w Europie. Poznań: Wydawnictwo Naukowe UAM (in Polish).

Kwiek, M. (2012a). Changing higher education policies: from the deinstitutionalization to the reinstitutionalization of the research mission in Polish universities. Science and Public Policy, 39(5).

Kwiek, M. (2012b). Universities, regional development and economic competitiveness: the Polish case. In R. Pinheiro, P. Benneworth, \& G. A. Jones (Eds.), Universities and regional development. A critical assessment of tensions and contradictions. New York: Routledge.

Kwiek, M. (2013a). Knowledge production in European universities. States, markets, and academic entrepreneurialism. Frankfurt and New York: Peter Lang.

Kwiek, M. (2013b). From system expansion to system contraction: access to higher education in Poland. Comparative Education Review, 57(3), 553-576.

Kwiek, M. (2014). Structural changes in the Polish higher education system (1990-2010): a synthetic view. European Journal of Higher Education, 4(3), 266-280.

Kwiek, M. (2015). From privatization (of the expansion era) to de-privatization (of the contraction era). A national counter-trend in a global context. In S. Slaughter, \& B. J. Taylor (Eds.), Stratification, privatization and employability of higher education in the US and $E U$. Dordrecht: Springer.

Kwiek, M. (2016). Constructing Universities as Organizations. University Reforms in Poland in the Light of Institutional Theory. In: E. Samier (Ed.), Educational Admnistration and Leadership. New York: Routledge.

Kwiek, M., \& Maassen, P. (Eds.). (2012). National higher education reforms in a European context: Comparative reflections on Poland and Norway. Frankfurt and New York: Peter Lang.

Levine, A., \& Associates (1990). Shaping higher education future: Demographic realities and opportunities, 1990-2000. San Francisco: Jossey-Bass Publishers.

Levy, D. C. (1986a). 'Private' and 'Public': analysis amid ambiguity in higher education. In D. C. Levy (Ed.), Private education. Studies in choice and public policy. Oxford: Oxford University Press.

Levy, D. C. (1986b). Higher education and the state in Latin America. Private challenges to public dominance. Chicago: The University of Chicago Press.

Levy, D. C. (2002). Unanticipated development: Perspectives on private higher education's emerging roles. PROPHE Working Paper Series no. 1. 
Levy, D. C. (2009). Growth and typology. In S. Bjarnason, et al. (Ed.), A new dynamic: Private higher education. Paris: UNESCO.

Levy, D. C. (2010). An international exploration of decline in private higher education. No. 61. Fall 2010. International Higher Education, 10-12.

Maassen, P., \& Olsen, J. P. (Eds.). (2007). University dynamics and European integration. Dordrecht: Springer.

Marcucci, P. (2013). The politics of student funding policies from a comparative perspective. In: D. E. Heller, \& C. Callender, (Eds.), Student Financing of Higher Education. A Comparative Perspective. Routledge: New York.

Marginson, S. (1997). Markets in education. St. Leonards: Allen \& Unwin.

Meek, V. L., Goedegebuure, L., Kivinen, O., \& Rinne, R. (1996). Conclusion. In V. L. Meek, L. Goedegebuure, O. Kivinen, \& R. Rinne (Eds.), The mockers and mocked: Comparative perspectives on differentiation, convergence and diversity in higher education. Bingley: Emerald.

MoSHE. (2012). Projekt zalozen projektu ustawy o zmianie ustawy - Prawo o szkolnictwie wyzszym oraz niektorych innych ustaw. Warsaw: Ministry of Science and Higher Education (mimeo).

Neave, G., \& Amaral, A. (Eds.). (2012). Higher education in Portugal 1974-2009: A nation, a generation. Dordrecht: Springer.

OECD. (2004). OECD handbook for internationally comparative education statistics. Concepts, standards, definitions and classifications. Paris: OECD.

OECD. (2006). Think scenarios, rethink education. Paris: OECD.

Scott, P. (2007). Reflections on private higher education tendencies in Central and Eastern Europe. In S. Slantcheva, \& D. C. Levy (Eds.), Private higher education in Post-Communist Europe. In search of legitimacy. New York: Palgrave.

Shavit, Y., Arum, R., \& Gamoran, A. (Eds.). (2007). Stratification in higher education: A comparative study. Stanford: Stanford University Press.

Slantcheva, S., \& Levy, D. C. (Eds.). (2007). Private higher education in Post-Communist Europe. In search of legitimacy. New York: Palgrave.

Teixeira, P., \& Amaral, A. (2001). Private higher education and diversity: an exploratory survey. Higher Education Quarterly, 55(4).

Teixeira, P., \& Amaral, A. (2007). Waiting for the tide to change? Strategies for survival of portuguese HEIs. Higher Education Quarterly, 61(2).

Teixeira, P. N. (2012). The changing public-private mix in higher education: analysing Portugal's apparent exceptionalism. In G. Neave, \& A. Amaral (Eds.), Higher education in Portugal 1974-2009: A nation, a generation. Dordrecht: Springer.

Trow, M. (2007). Reflections on the transition from elite to mass to universal access: forms and phases of higher education in modern societies since WWII. In J. J. F. Forest, \& P. G. Altbach (Eds.), International handbook of higher education. Dordrecht: Springer.

Vincent-Lancrin, S. (2008). What is the impact of demography on higher education systems? A forward-looking approach for OECD countries. Demography. In OECD, higher education to 2030 (Vol. 1). Paris: OECD.

Wasielewski, K. (2013). Mlodziez wiejska na uniwersytecie. Droga na studia, mechanizmy alokacji, postawy wobec ksztatcenia. Torun: Wydawnictwo UMK.

Woźnicki, J. (Ed.). (2013). Financing and deregulation in higher education. Warsaw: Institute of Knowledge Society.

Yonezawa, A., \& Kim, T. (2008). The future of higher education in the context of a shrinking student population: policy challenges for Japan and Korea. Demography. In OECD, higher education to 2030 (Vol. 1). Paris: OECD. 
Table 4.1 Enrollments by field of study in Poland, private sector, 2000-13

\begin{tabular}{|c|c|c|c|c|c|c|c|c|}
\hline $\begin{array}{l}\text { Academic } \\
\text { year }\end{array}$ & Education & $\begin{array}{l}\text { Humanities } \\
\text { and arts }\end{array}$ & $\begin{array}{l}\text { Social sciences, } \\
\text { economy and } \\
\text { law }\end{array}$ & Science & $\begin{array}{l}\text { Technology, } \\
\text { industry, } \\
\text { construction }\end{array}$ & Agriculture & $\begin{array}{l}\text { Health and } \\
\text { welfare }\end{array}$ & Services \\
\hline 2000 & 54,042 & 12,610 & 320,487 & 19,992 & 7166 & 1613 & 267 & 12,776 \\
\hline 2001 & 57,126 & 22,324 & 321,474 & 25,593 & 3771 & 1543 & 488 & 19,077 \\
\hline 2002 & 62,588 & 23,750 & 315,751 & 28,867 & 4172 & 1395 & 949 & 23,969 \\
\hline 2003 & 65,590 & 24,768 & 299,009 & 33,195 & 4957 & 1394 & 1897 & 26,355 \\
\hline 2004 & 68,949 & 24,846 & 297,273 & 36,239 & 3005 & 1510 & 4937 & 30,250 \\
\hline 2005 & 71,278 & 32,019 & 306,659 & 33,992 & 5400 & 1817 & 8980 & 35,946 \\
\hline 2006 & 94,803 & 42,984 & 367,797 & 51,082 & 11,483 & 2519 & 20,322 & 49,323 \\
\hline 2007 & 98,566 & 47,271 & 370,175 & 47,668 & 13,977 & 2685 & 26,868 & 53,257 \\
\hline 2008 & 102,175 & 42,231 & 367,577 & 41,969 & 16,125 & 2603 & 29,984 & 56,732 \\
\hline 2009 & 107,341 & 36,315 & 344,252 & 34,858 & 17,598 & 2343 & 34,625 & 55,765 \\
\hline 2010 & 97,025 & 34,164 & 305,600 & 28,781 & 19,541 & 1896 & 37,213 & 55,856 \\
\hline 2011 & 84,212 & 33,342 & 265,780 & 24,767 & 19,640 & 1572 & 32,869 & 56,014 \\
\hline 2012 & 69,973 & 30,827 & 229,545 & 21,969 & 19,090 & 1348 & 33,160 & 53,538 \\
\hline 2013 & 53,761 & 29,460 & 195,473 & 20,122 & 17,189 & 1345 & 30,683 & 50,529 \\
\hline
\end{tabular}

GUS. (2014). Higher education institutions and their finances in 2013 (pp. 64-65). Warsaw: GUS (Central Statistical Office) and previous editions. 
Table 4.2 Share of enrollments by field of study in Poland, private sector, 2000-13 (in \%)

\begin{tabular}{|c|c|c|c|c|c|c|c|c|c|}
\hline $\begin{array}{l}\text { Academic } \\
\text { year }\end{array}$ & $\begin{array}{l}\text { Education } \\
(\%)\end{array}$ & $\begin{array}{l}\text { Humanities } \\
\text { and arts } \\
(\%)\end{array}$ & $\begin{array}{l}\text { Social } \\
\text { sciences, } \\
\text { economy and } \\
\text { law }(\%)\end{array}$ & $\begin{array}{l}\text { Science } \\
(\%)\end{array}$ & $\begin{array}{l}\text { Technology, } \\
\text { industry, } \\
\text { construction } \\
(\%)\end{array}$ & $\begin{array}{l}\text { Agriculture } \\
(\%)\end{array}$ & $\begin{array}{l}\text { Health and } \\
\text { welfare }(\%)\end{array}$ & $\begin{array}{l}\text { Services } \\
(\%)\end{array}$ & $\begin{array}{l}\text { Total } \\
(\%)\end{array}$ \\
\hline 2000 & 12.60 & 2.94 & 74.71 & 4.66 & 1.67 & 0.38 & 0.06 & 2.98 & 100.00 \\
\hline 2001 & 12.66 & 4.95 & 71.22 & 5.67 & 0.84 & 0.34 & 0.11 & 4.23 & 100.00 \\
\hline 2002 & 13.56 & 5.15 & 68.43 & 6.26 & 0.90 & 0.30 & 0.21 & 5.19 & 100.00 \\
\hline 2003 & 14.35 & 5.42 & 65.41 & 7.26 & 1.08 & 0.30 & 0.41 & 5.76 & 100.00 \\
\hline 2004 & 14.76 & 5.32 & 63.65 & 7.76 & 0.64 & 0.32 & 1.06 & 6.48 & 100.00 \\
\hline 2005 & 14.37 & 6.45 & 61.82 & 6.85 & 1.09 & 0.37 & 1.81 & 7.25 & 100.00 \\
\hline 2006 & 14.81 & 6.71 & 57.44 & 7.98 & 1.79 & 0.39 & 3.17 & 7.70 & 100.00 \\
\hline 2007 & 14.92 & 7.16 & 56.05 & 7.22 & 2.12 & 0.41 & 4.07 & 8.06 & 100.00 \\
\hline 2008 & 15.50 & 6.40 & 55.74 & 6.36 & 2.45 & 0.39 & 4.55 & 8.60 & 100.00 \\
\hline 2009 & 16.95 & 5.74 & 54.38 & 5.51 & 2.78 & 0.37 & 5.47 & 8.81 & 100.00 \\
\hline 2010 & 16.73 & 5.89 & 52.68 & 4.96 & 3.37 & 0.33 & 6.42 & 9.63 & 100.00 \\
\hline 2011 & 16.25 & 6.43 & 51.29 & 4.78 & 3.79 & 0.30 & 6.34 & 10.81 & 100.00 \\
\hline 2012 & 15.23 & 6.71 & 49.96 & 4.78 & 4.15 & 0.29 & 7.22 & 11.65 & 100.00 \\
\hline 2013 & 13.49 & 7.39 & 49.04 & 5.05 & 4.31 & 0.34 & 7.70 & 12.68 & 100.00 \\
\hline
\end{tabular}

GUS. (2014). Higher education institutions and their finances in 2013 (pp. 64-65). Warsaw: GUS (Central Statistical Office) and previous editions. 


\title{
A Global Perspective on Private Higher Education
}

\author{
Edited by
}

\section{Mahsood Shah \\ Chenicheri Sid Nair}

AMSTERDAM • BOSTON • CAMBRIDGE • HEIDELBERG

LONDON • NEW YORK • OXFORD • PARIS • SAN DIEGO

SAN FRANCISCO • SINGAPORE • SYDNEY • TOKYO

Chandos Publishing is an imprint of Elsevier

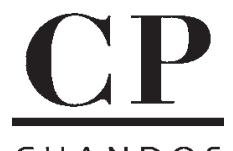

CHANDOS PUBLISHING 
Chandos Publishing is an imprint of Elsevier

50 Hampshire Street, 5th Floor, Cambridge, MA 02139, USA

The Boulevard, Langford Lane, Kidlington, OX5 1GB, UK

Copyright () 2016 Mahsood Shah and Chenicheri Sid Nair. Published by Elsevier Ltd. All rights reserved.

No part of this publication may be reproduced or transmitted in any form or by any means, electronic or mechanical, including photocopying, recording, or any information storage and retrieval system, without permission in writing from the publisher. Details on how to seek permission, further information about the Publisher's permissions policies and our arrangements with organizations such as the Copyright Clearance Center and the Copyright Licensing Agency, can be found at our website: www.elsevier.com/permissions.

This book and the individual contributions contained in it are protected under copyright by the Publisher (other than as may be noted herein).

\section{Notices}

Knowledge and best practice in this field are constantly changing. As new research and experience broaden our understanding, changes in research methods, professional practices, or medical treatment may become necessary.

Practitioners and researchers must always rely on their own experience and knowledge in evaluating and using any information, methods, compounds, or experiments described herein. In using such information or methods they should be mindful of their own safety and the safety of others, including parties for whom they have a professional responsibility.

To the fullest extent of the law, neither the Publisher nor the authors, contributors, or editors, assume any liability for any injury and/or damage to persons or property as a matter of products liability, negligence or otherwise, or from any use or operation of any methods, products, instructions, or ideas contained in the material herein.

\section{British Library Cataloguing-in-Publication Data}

A catalogue record for this book is available from the British Library

\section{Library of Congress Cataloging-in-Publication Data}

A catalog record for this book is available from the Library of Congress

ISBN: 978-0-08-100872-0 (print)

ISBN: 978-0-08-100898-0 (online)

For information on all Chandos Publishing publications visit our website at https://www.elsevier.com/

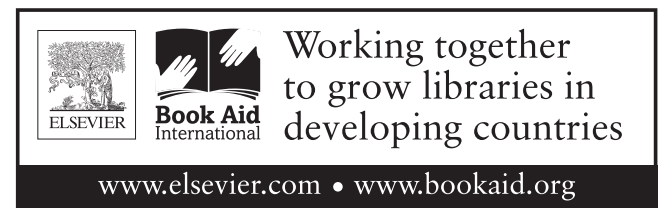

Publisher: Glyn Jones

Acquisition Editor: George Knott

Editorial Project Manager: Harriet Clayton

Production Project Manager: Poulouse Joseph

Designer: Greg Harris

Typeset by TNQ Books and Journals 